\title{
Assessment of Lake Tourism Object as Ecotourism Destination in Merabu, Berau Regency, East Kalimantan
}

\author{
Iin Sumbada Sulistyorini ${ }^{1 *}$, Jerlita Kadang Allo ${ }^{1}$, Muli Edwin ${ }^{1}$, Rosdianto ${ }^{2}$ \\ ${ }^{1}$ Forestry Study Program, Sekolah Tinggi Ilmu Pertanian (STIPER) Kutai Timur. Jl. Sukarno-Hatta 01, Sangatta, 75387, East \\ Kalimantan, Indonesia \\ ${ }^{2}$ Marine Science Study Program, Sekolah Tinggi Ilmu Pertanian (STIPER) Kutai Timur. Jl. Sukarno-Hatta 01, Sangatta, 75387, \\ East Kalimantan, Indonesia \\ * Corresponding Author. E-mail address: iinsumbada@stiperkutim.ac.id
}

\section{ARTICLE HISTORY:}

Received: 6 November 2021

Peer review completed: 5 January 2022 Received in revised form: 9 January 2022 Accepted: 24 January 2022

\section{KEYWORDS:}

\section{Blue lake}

Ecotourism

Merabu Village Forest

Nya'deng Lake
C 2022 The Author(s). Published by Department of Forestry, Faculty of Agriculture, University of Lampung in collaboration with Indonesia Network for Agroforestry Education (INAFE).

This is an open access article under the CC BY-NC license:

https://creativecommons.org/licenses/by$\mathrm{nc} / 4.0 /$

\begin{abstract}
Nya'deng Lake, also called the blue lake, is located in the Sangkulirang Mangkaliat Karst landscape area and is included in the Merabu Village Forest area. Natural lakes with certain uniqueness and characteristics as Nya'deng Lake have become a tourist attraction in Indonesia. Therefore, assessing natural tourism in the lake is very important to develop environmentally friendly and responsible tourism. This research was conducted to explore and assess the potential of Nya'deng Lake as a lake tourism site. The study used a qualitative descriptive approach using a scoring method. Based on field observation, Nya;deng Lake is unique in terms of beauty, comfort, variety of activities, and environmental cleanliness. There are also other interesting objects such as tree houses and gazebos surrounding the lakeside. The results showed that the natural tourism object in Nya'deng Lake has very high criteria; hence it is very feasible to be developed as an ecotourism destination. The ecotourism development of Nya'deng Lake should follow the principles of sustainability and conservation because it is a protected geological area with prehistoric, cultural, and unique natural ecosystem values.
\end{abstract}

\section{Introduction}

Forests are essential habitats for biodiversity and provide various essential ecosystem services for human well-being (Brockerhoff et al. 2017). Promoting forest conservation and the well-being of the community surrounding the forests requires an appropriate balance of regulation, enforcement, and incentives. One management option for promoting low-intensity and nondeleterious forest use includes utilizing non-timber forest products (NTFPs) and environmental services (Harbi et al. 2018). One form of non-consumptive use of forest environmental services is nature tourism or ecotourism (Achmad et al. 2012). The development of ecotourism destinations is expected to improve the local community's economy within and around the forests (Edwin et al. 2017). Ecotourism in sustainable development has become a global issue widely discussed in Indonesia (Butarbutar and Soemarno 2013). Ecotourism is a sub-component of the field of sustainable tourism. Ecotourism contributes to the conservation of biodiversity, supports the wellbeing of local communities, involves responsible action on the part of tourists and the tourism industry. Tourism is a large and dispersed global industry (Buckley 2011). 
Currently, ecotourism has been defined in many ways and various perspectives. Ecotourism is a type of tourism that requires environmentally responsible recreational activities within designated natural areas, and established policies that encourage the protection of natural areas with minimal adverse effects and visitors can contribute to the socio-economic development of the local population (Aç1ksöz et al. 2016). Conservation-based tourism is an important principle in the vision of ecotourism. The development of ecotourism services in villages includes efforts to develop local empowerment infrastructure to fulfill environmental conservation, build governance for community welfare, and educate on cultural and environmental conservation (Nugroho et al., 2018). Sustainable ecotourism based on ecology should be the ultimate goal in its development (Wang et al. 2014).

The current expansion of oil palm plantations and the cement industry can threaten the integrity of the Sangkulirang Mangkalat Karst as a world cultural heritage (Sumantri et al. 2017). The Merabu area in Berau Regency is part of the Sangkulirang Mangkaliat Karst protected area. Apart from having dozens of caves in the area, it also has many water sources, such as lakes (Reinhart et al. 2020). Based on the field observation in Merabu, there is a village forest and tourism development, and one of the objects is Nya'deng Lake. However, Merabu Village is an underdeveloped village and has not been a priority for tourism development by the Berau Regency Government. Therefore, information related to tourism potential is needed to encourage the village economy (Roy et al. 2021).

A benchmark is needed to determine the influence factors that could support or hinder tourism development (Suharto et al. 2019). Information and related research on tourism potential in the Nya'deng Lake are challenging to obtain. This research is a new thing that is expected to introduce more widely about the tourism potential of Nya' deng Lake. Research on assessing tourist attractions in the lake is expected to help provide additional information for ecotourism development in the forestry sector. Nya'deng Lake, located in the Village Forest area and part of the karst landscape, should be explored further in the hope that developing natural tourism can later function as environmentally friendly, responsible tourism and lead to an increase in the economy of the local community.

\section{Materials and Methods}

\subsection{Study Area}

This research was carried out in Nya'deng Lake from June to August 2021. The lake is a part of the Sangkulirang Mangkaliat Karst geological protected area with a geographical position of $1^{\circ} 26^{\prime} 14.62$ " N and $117^{\circ} 17^{\prime} 30.76$ " E (Fig. 1). Administratively, Nya'deng Lake belongs to the Merabu Village area, Kelay district, Berau regency, East Kalimantan. Merabu Village is adjacent to the natural forest concessions and oil palm plantation concessions.

\subsection{Methods}

This research used a descriptive qualitative approach. The descriptive study seeks to describe the current problem solving based on data and understand the phenomenon of the research subject's happening and experience. Quantitative descriptive, in this case, is a description of the results of the use of instruments, namely surveys and documentation in collecting data to determine the potential of lake tourist attractions. 


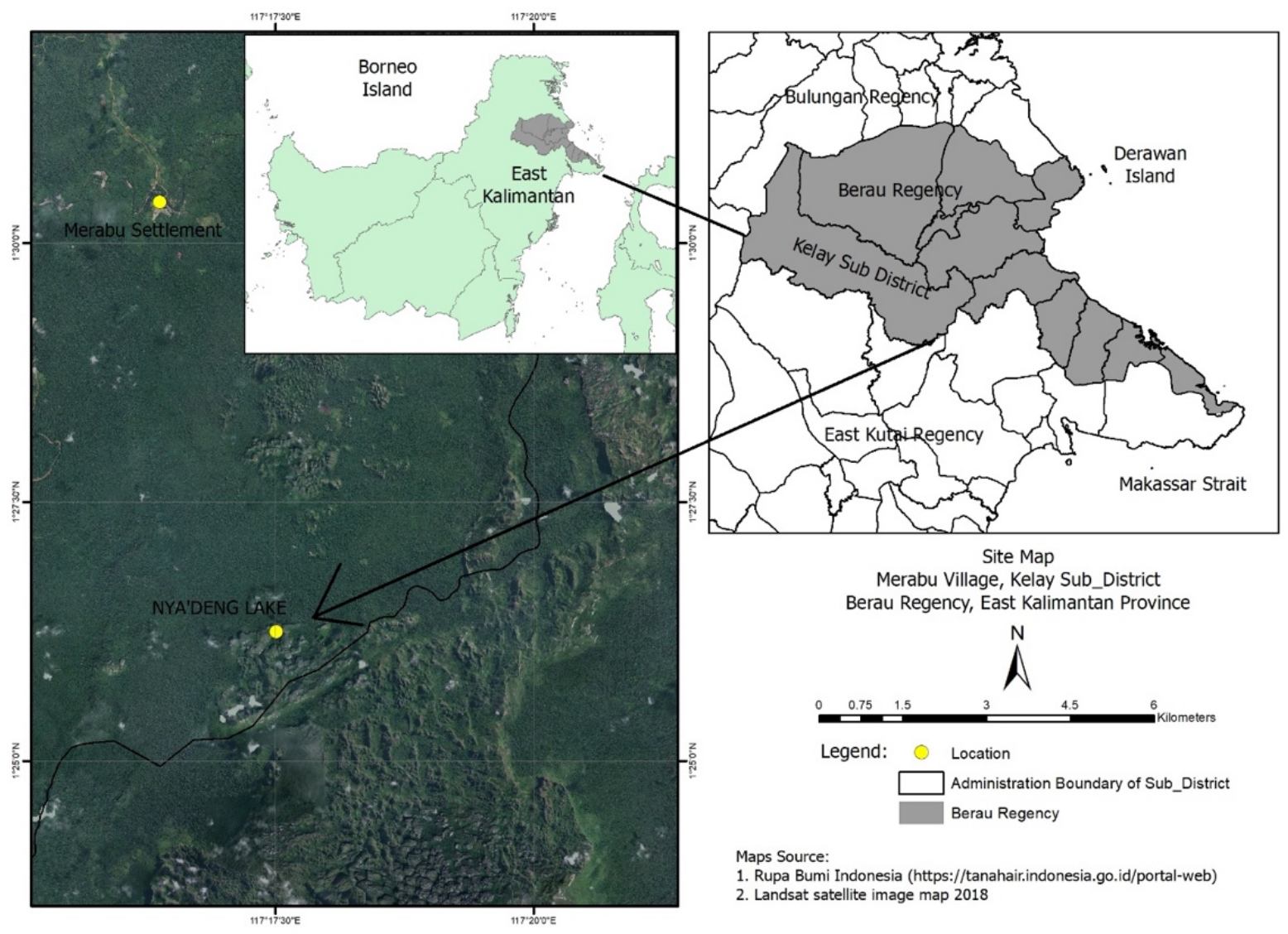

Fig. 1. The study area in Nya'deng Lake, Merabu Village.

\subsubsection{Field observation}

Field observation was carried out to find out the general description and condition of the research location. This activity also seeks information that can support research. Observation activities began with a visit to Merabu Village and continued to Nya'deng Lake. Field observation was carried out during the pre-survey and the implementation of the research.

\subsubsection{Data collection}

The data collected in this study consists of primary and secondary data. Primary data was obtained through direct observations of the research object with guidelines following the criteria that had been prepared (Table 1). Secondary data were obtained from literature studies, previous research reports, and other sources relevant to this research. The data collected consisted of six elements, including the object of tourist attraction in the form of a lake, accessibility, accommodation, availability of clean water, the relationship of the object with the surrounding tourism, and the carrying capacity of the environment. In addition, certain elements related to the distance $(\mathrm{km})$ of the lake location to the district capital, land cover, and others were obtained with the help of map processing using a Geographic Information System (GIS), and maps were produced in ArcMap 10.3. 


\subsubsection{Data Analysis}

The data analysis in this study adopted the Guidelines for Operation Areas Analysis of Natural Tourist Attraction and Object or Analisis Daerah Operasi Obyek dan Daya Tarik Wisata Alam (ADO-ODTWA) (Ministry of Forestry, 2003). The analysis used a scoring approach to the identified elements and sub-elements. The score of each element consists of five levels, namely 10, 15, 20, 25, and 30. Each score represents the number of assessments in each sub-element. For example, the sub-element of convenience met two of the five assessed, namely on the lake air is cool and noise-free, the score is 15 . The value of each sub-element multiplied by the weight was added to see the minimum and maximum total scores (Table 1).

Table 1. Assessment for natural tourist attractions and objects for a natural lake

\begin{tabular}{|c|c|c|c|c|}
\hline \multirow{2}{*}{ No. } & \multirow{2}{*}{ Element/Sub element } & \multirow{2}{*}{ Weights } & \multicolumn{2}{|c|}{ Score $\times$ Weight } \\
\hline & & & Min & Maks \\
\hline \multirow[t]{9}{*}{1} & Natural tourist attractions and objects (ODTWA) & 6 & & \\
\hline & - The beauty of the lake & & 60 & 180 \\
\hline & - Convenience & & 60 & 180 \\
\hline & - Safety & & 60 & 180 \\
\hline & - Water stability throughout the year & & 60 & 180 \\
\hline & - Variety of activities in the lake & & 60 & 180 \\
\hline & - Variety of activities around the lake & & 60 & 180 \\
\hline & - The uniqueness of the environment in the lake & & 60 & 180 \\
\hline & - Cleanliness of the lake water and environment & & 60 & 180 \\
\hline \multirow[t]{2}{*}{2} & Accessibility & 5 & & \\
\hline & - Distance from the district capital/airport (km) & & 50 & 150 \\
\hline \multirow[t]{2}{*}{3} & Accommodation & 3 & & \\
\hline & - Number of rooms/lodging & & 30 & 90 \\
\hline \multirow[t]{2}{*}{4} & Availability of clean water & 6 & & \\
\hline & - Distance of clean water source to object & & 60 & 180 \\
\hline \multirow[t]{2}{*}{5} & Relationship with surrounding attractions & 1 & & \\
\hline & - Distance and number of other objects & & 20 & 30 \\
\hline \multirow[t]{5}{*}{6} & Carrying capacity of environmental & 3 & & \\
\hline & - Number of visitors & & 30 & 90 \\
\hline & - Land slope (\%) & & 30 & 90 \\
\hline & - Area of unit/zone that can be utilized (ha) & & 30 & 90 \\
\hline & - Land cover type & & 30 & 90 \\
\hline & Total score & & 760 & 2,250 \\
\hline
\end{tabular}

Note: based on Guidelines for Operation Areas Analysis of Natural Tourist Attraction (ADO-ODTWA) (Ministry of Forestry 2003), which were modified.

Based on the minimum and maximum total scores, four criteria for the development potential of natural tourist attractions and objects or Obyek dan Daya Tarik Wisata Alam (ODTWA) in the form of lakes were established (Table 2). 
Table 2. The potential level of ODTWA development in the form of natural lake

\begin{tabular}{|c|c|c|c|}
\hline \multirow{2}{*}{ No. } & \multirow{2}{*}{ The potential level of ODTWA } & \multicolumn{2}{|c|}{ Range of total score } \\
\hline & & Min & Maks \\
\hline 1 & Very low (not proper to develop) & 760 & 1,133 \\
\hline 2 & Low (not yet feasible to develop) & 1,134 & 1,507 \\
\hline 3 & Height (proper to develop) & 1,508 & 1,881 \\
\hline 4 & Very high (very proper to develop) & 1,882 & 2,250 \\
\hline
\end{tabular}

\section{Results and Discussion}

\subsection{Description of the Study Area}

The journey to the study site was started from the Sangatta City, East Kutai Regency, to Kelay District, Berau Regency. Then from the highway to Merabu Village through the oil palm plantation area, about a 1 hour drive. The village settlements are mainly located on the Lesan River border. The village is inhabited by indigenous people, namely the Lebo Dayak. The village has a uniqueness ranging from wooden houses, ornaments, and cultural arts from the indigenous people.

The journey from the village to the location of Nya'deng Lake has an exciting adventure challenge. The first is a trip down the river using a small boat with views of the tropical forest on either side, then continue the tropical forest tracking trip to get to the lake. The journey from the village to the lake took around 1 hour. The lake is still surrounded by dense natural tropical forests. Around the lake, there are several facilities such as gazebos, treehouses, seats, tents, hammocks for rent, and others. The lake has a relatively large location with fascinating views of the surrounding forests, allowing for various activities to be carried out. The lake water is bluish and transparent so that the bottom of the lake can be seen. The uniqueness of the lake is influenced by the condition of the forest in the Sangkulirang-Mangkaliat karst area.

Since 2000, Berau Regency in East Kalimantan has been in the spotlight because it has the potential for exotic natural tourist attractions and objects, especially marine ecotourism destinations in Derawan, Maratua, and Sangalaki (Pulungan 2013; Roy et al. 2021). In the mainland region of Berau, there is also much potential for high natural resources, especially tropical rain forests and the Sangkulirang-Mangkaliat Karst. The natural resources have given rise to many ecotourism destinations such as waterfalls, lakes, hot springs, and others scattered in the karst area. Nya'deng Lake in Merabu Village is one of the lakes surrounded by natural forests with high flora diversity.

Merabu Village in Kelay District, Berau, is located downstream of the Lesan River inhabited by indigenous people, namely the Lebo Dayak tribe (Rahma et al. 2020). The village area is 389.55 $\mathrm{km}^{2}$, and the population in 2019 was 234 people with a population density of $0.60 \mathrm{~km}^{2}$ (BPS Berau 2021). The term lebo comes from leppo or lepau, which means hut or house. The term Merabu comes from the word Minangga Bu, which means estuary of the Bu River according to the settlements located downstream of the river. The Lebo Dayak community still preserves traditional culture and rituals like Tuaq Manuk, which expresses gratitude for forest products, agriculture, and community peace (Roy et al. 2021). In the village, there is a Village Forest or Hutan Desa (HD) according to the Decree of the Minister of Forestry No: 28/Menhut-II/2014 dated 9 January 2014, regarding the Designation of the Merabu Village Forest Working Area covering an area of 8,245 ha. Natural tourism potentials in the forest include Nya'deng Lake, tree adoption, and tracking 
trails. Then there are also other tourist objects such as prehistoric cave tourism (Beloyot Cave) and educational tourism in the form of the Kerima Puri Library (Roy et al. 2019).

\subsection{Potential Assessment of Natural Tourism Object of Nya'deng Lake}

\subsubsection{Potential attractions of Nya'deng Lake}

Nya'deng Lake around the Sangkulirang Mangkaliat karst has a unique blue color (Fig. 2). The karst area has a total area of 362,706.11 ha according to Governor Regulation No. 67 of 2012 concerning Protection and Management of the Sangkulirang Mangkaliat Karst Ecosystem in Berau and East Kutai Regencies. The karst area has provided water sources for most rivers such as the Bengalon River, Kelay River, and Sangkulirang River (Reinhart et al. 2020). Research in the karst stated that the source of the blue lake water of Nya'deng Lake comes from springs from groundwater flows. The blue lake color has an excellent aesthetic, and the water is clean with a bluish color due to the influence of carbonate content, tasteless, and odorless (Fathoni et al. 2020).

Nya'deng Lake is flooded with fresh water, which is still part of the Sangkulirang Mangkaliat karst landscape and has tremendous natural potential. Since 2015, the lake and several other objects in Merabu Village have started to be managed as tourist destinations. There are many tourist destinations in Berau, so tourism development in Merabu has not become a development priority scale. An exploratory study should be conducted to strengthen ecotourism development in the area, such as assessing ODTWA. The assessment of the eight elements of ODTWA has found four elements with a maximum score and no elements with a minimum score (Table 3).

Table 3. The score of the assessment results of natural tourism object of Nya' deng Lake

\begin{tabular}{|c|c|c|c|}
\hline \multirow{2}{*}{ No. } & \multirow{2}{*}{ Element of assessment } & \multicolumn{2}{|c|}{ Assessment results } \\
\hline & & Score & Score $\times$ Weight \\
\hline 1 & The beauty of the lake & 30 & 180 \\
\hline 2 & Convenience & 30 & 180 \\
\hline 3 & Safety & 25 & 150 \\
\hline 4 & Water stability throughout the year & 20 & 120 \\
\hline 5 & Variety of activities on the lake & 30 & 180 \\
\hline 6 & Variety of activities around the lake & 25 & 150 \\
\hline 7 & The uniqueness of the environment in the lake & 25 & 150 \\
\hline \multirow[t]{2}{*}{8} & The cleanliness of lake water and the environment & 30 & 180 \\
\hline & Total score & & 1,290 \\
\hline
\end{tabular}

Four elements with maximum scores are the beauty of the lake, convenience, variety of activities on the lake, and the cleanliness of lake water and the environment (Table 3). The beauty of the lake has five sub-elements: the beautiful view of the journey to the lake, the beautiful view from in the lake, the harmony of the building with the environment, the harmony of the atmosphere, and the beauty on the base of the lake. The convenience element has five subelements: free of disturbing odors, gently sloping lakeside, no public traffic, fresh air, and noisefree. The element of a variety of activities on the lake has five sub-elements, namely hiking, enjoying nature, local cultural arts attractions, education, and camping. Finally, the cleanliness of lake water and the environment has five sub-elements, including no settlement effect, siltation, factory influence, garbage, and clear lake water. 

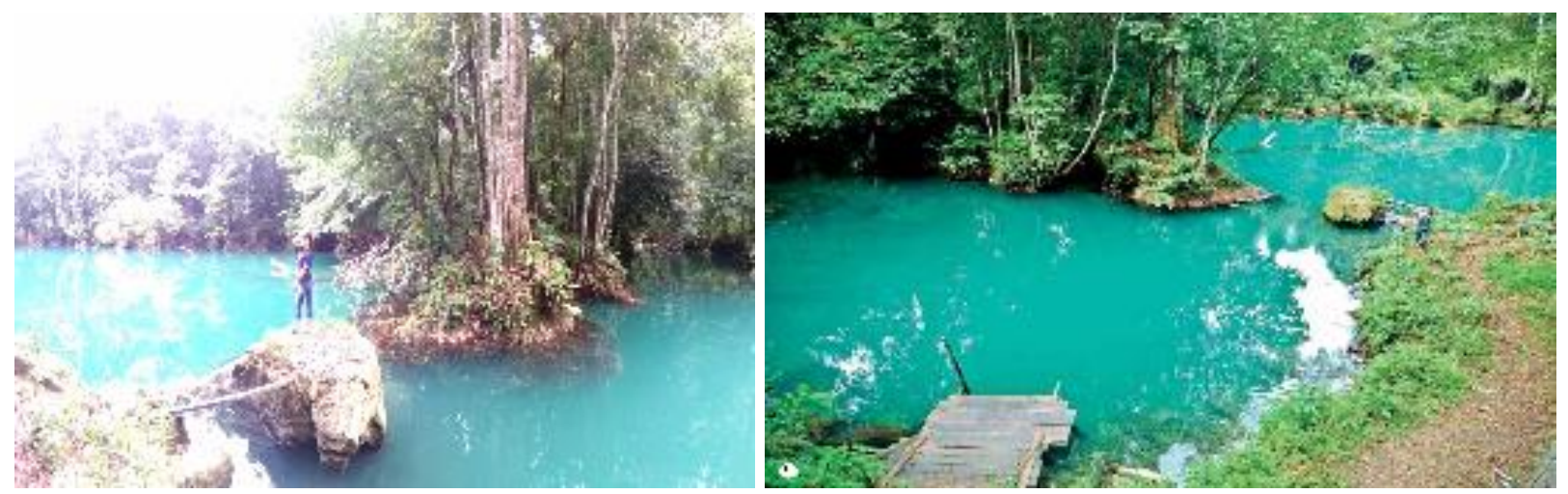

Fig. 2. Nya'deng Lake shows blue water surrounded by forest in Merabu Village.

The safety element fulfills four sub-elements: no dangerous currents in the lake, free from harmful plant disturbances, free from human interference, and free from disturbing beliefs. The variety of activities around the lake fulfills four sub-elements: canoeing, swimming, education and research, and enjoying the scenery. The peculiarities of the lake environment are flora, fauna, local cultural peculiarities, and historical value. The stability of the water in the lake met the subelements, which are: there is no lake water user industry, no reduction in land cover around the lake, rainfall throughout the year because it is a tropical rain forest area, and there is no erosion/landslide in the heavy category.

Ecotourism development must pay attention to environmental, cultural preservation, and integration planning (Nugroho et al. 2018). Ecotourism activities oriented to natural resources, natural ecosystems, and have not been polluted must minimize negative impacts on the environment and local socio-cultural (Butarbutar and Soemarno 2013). Developing trends in ecotourism policies in Indonesia are conservation, ecology, and community participation (Sisriany and Furuya 2020). Based on the ODTWA potential of Nya'deng Lake, the orientation of ecotourism policies must be based on conservation, empowerment of local communities, and integrated planning with local governments. The lake is part of the Sangkulirang-Mangkaliat karst landscape, a protected geological area. Therefore, the appropriate tourism to be implemented is alternative tourism or special interest tourism such as cultural, adventure, and nature-based tourism. Local and foreign tourists often visit the lake, especially on holidays. However, no special policy regulates permits to enter the lake area for foreign tourists. The local government must encourage this policy so that it can contribute to increasing the preservation of culture and economy local, especially for the indigenous people in Merabu Village.

\subsection{Potential Supports}

Referring to the ADO-ODTWA guidelines, other essential elements were assessed, consisting of five elements and eight sub-elements (Table 4). Of these eight sub-elements, the were no sub-element with a minimum score of 5. The results showed that the lowest score was 20, namely on accessibility to get to Nya'deng Lake. The distance from the airport at the capital of Berau Regency to Merabu Village is about $120 \mathrm{~km}$. However, not all roads are covered with asphalt surfaces. Some routes go through palm company roads with rocky conditions before reaching the Merabu Village (Fig. 3a). The distance from Merabu Village to the lake is about 9 $\mathrm{km}$, about 1 hour by car or 1.5 hours by small boat (ketinting) along the Lesan River (Fig. 3b), and another 0.5 hours on foot to get to the lake. 
Table 4. The score of assessment result of the potential supports of Nya'deng Lake tourist objects and attractions

\begin{tabular}{|c|c|c|c|}
\hline \multirow{2}{*}{ No. } & \multirow{2}{*}{ Elements and sub-elements of assessment } & \multicolumn{2}{|c|}{ Assessment results } \\
\hline & & Score & Score $\times$ Weight \\
\hline \multirow[t]{2}{*}{1} & Accessibility & & \\
\hline & - Distance from the district capital/airport (km) & 20 & 100 \\
\hline \multirow[t]{2}{*}{2} & Accommodation & & \\
\hline & - Number of rooms/lodging & 30 & 90 \\
\hline \multirow[t]{2}{*}{3} & Availability of clean water & & \\
\hline & - Distance of clean water to object & 30 & 180 \\
\hline \multirow[t]{2}{*}{4} & Relationship with surrounding attractions & & \\
\hline & - Distance and number of other objects & 25 & 50 \\
\hline \multirow[t]{6}{*}{5} & Carrying capacity of environmental & & \\
\hline & - Number of visitors & 30 & 90 \\
\hline & - Land slope (\%) & 25 & 75 \\
\hline & - Area of unit/zone that can be utilized (ha) & 20 & 60 \\
\hline & - Land cover type & 30 & 90 \\
\hline & Total score & & 735 \\
\hline
\end{tabular}
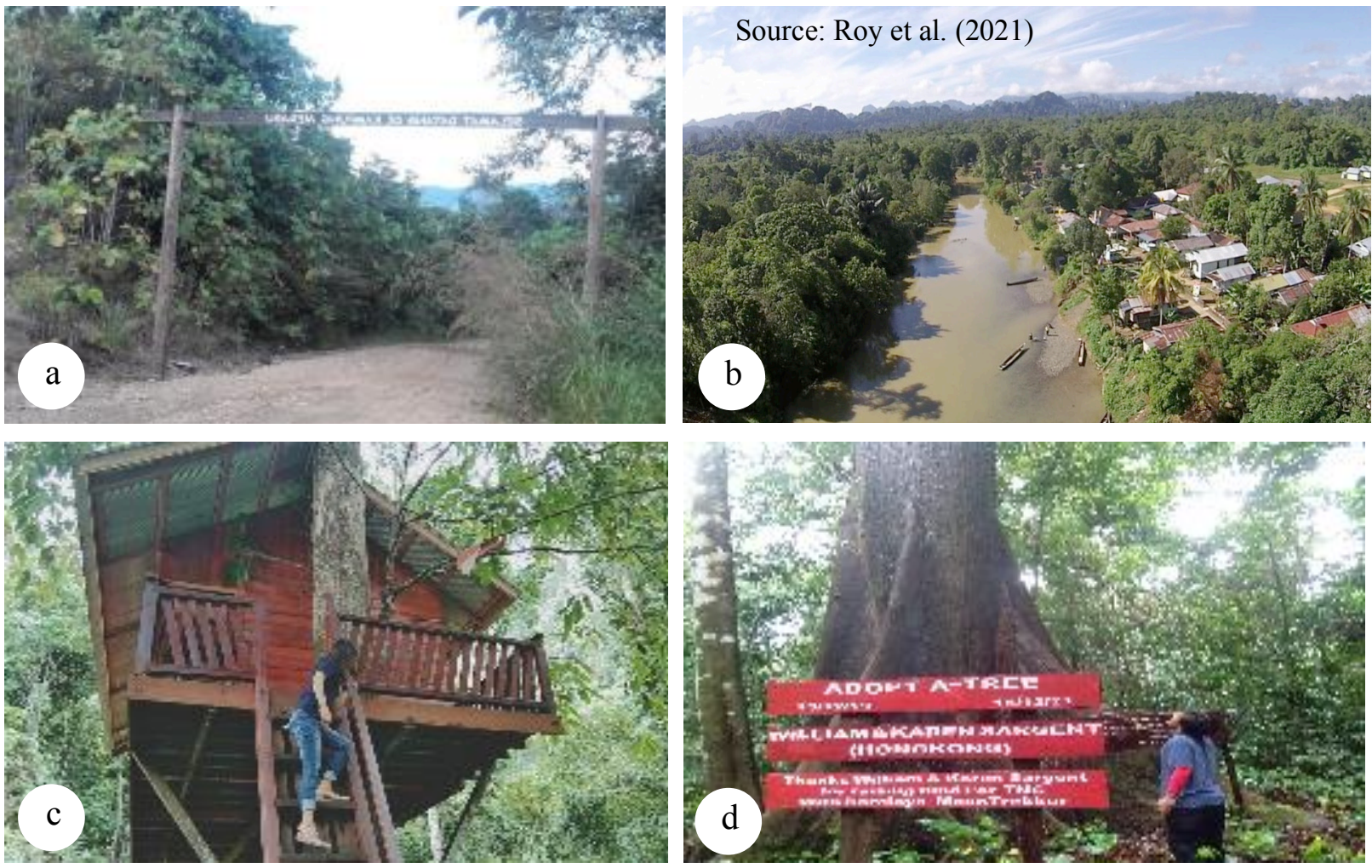

Fig. 3. Potential supports of Nya'deng Lake tourist objects and attractions: (a) the road to Merabu Village, (b) Lesan River, (c) treehouse, and (d) adopt a tree.

There is a treehouse with two bedrooms that visitors can rent (Fig. 3c). Accommodation for the number of rooms within a radius of $15 \mathrm{~km}$. There are homestays or houses in the village that can accommodate several people. There is also lodging that has three rooms managed by Kerima Puri. Kerima Puri is the Village Forest Management Agency which also manages the 
development of ecotourism in the village. In the Lebo Dayak language, kerima puri means beautiful or beautiful forest.

Nya'deng Lake water is used as a source of clean water, which is channeled to residential areas in Merabu Village. In addition to the lake, there are other tourist attractions such as Mount Ketepu with a distance of \pm 1 hour, Beloyot Cave with a distance of \pm 2.5 hours from the village on foot, and Kabilah Cave with distance from Beloyot Cave \pm 2.5 hours on foot. In the caves, there are prehistoric relics in the form of rock art painted on the walls and sky of the cave.

Nya'deng Lake is located in the upstream of the Lesan River with a land slope of 8-15\%. On holidays, visits to the lake can reach 50 to 100 people/day, while on weekdays, it is under 50 people/day. Based on the distribution of the lake and its surrounding environment using a map or satellite imagery, it is known that the area of the zone that can be used for ecotourism activities is estimated to be around 160 ha (Fig. 4). Based on field observations, the land cover type around the lake is the old secondary forest with high floristic diversity, which is the general characteristic of the natural tropical rain forest.

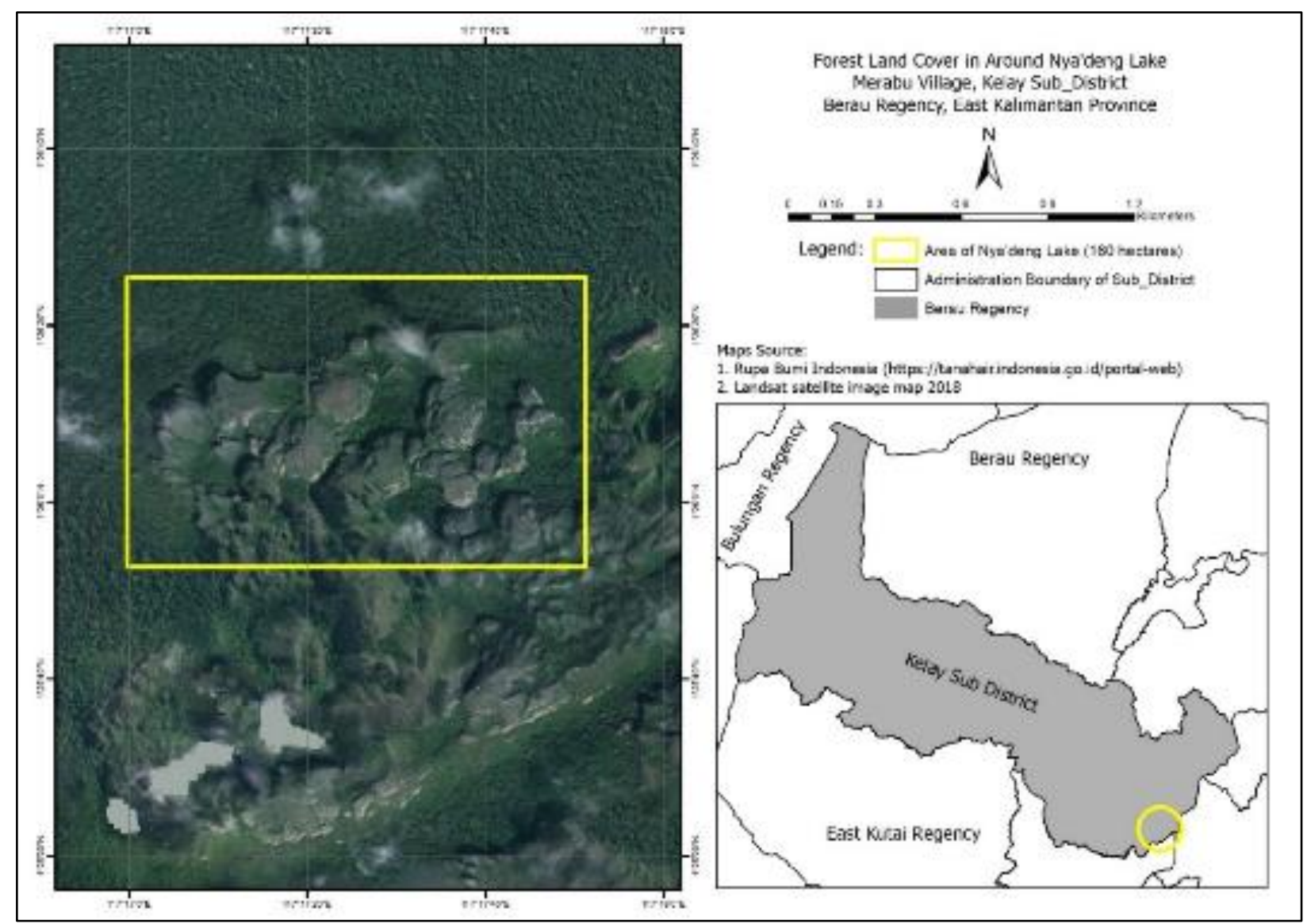

Fig. 4. Forest land cover around Nya'deng Lake in Merabu Village.

\subsection{Development Potential Level of Nya'deng Lake}

The ODTWA development criteria based on the sum of the total scores in Tables 3 and 4 are categorized as very high $(1,848-2,250)$ with a total score of 2,025 . The development is urgently needed, especially regarding accessibility, where there are some routes from Merabu Village to the lake that are still dirt and rocky roads. Another development potential is the preparation of Nya'deng Lake tour packages according to their potential. Such development 
requires the involvement of relevant local government agencies and other private institutions. The village forest management agency that existed in Merabu Village, such as Kerima Puri, should receive continuous guidance so that the ecotourism of the lake develops according to the orientation, namely responsible ecotourism based on conservation empowerment local communities and integrated planning. The role of academicians and environmentalists is also required to introduce, promote and strengthen the concept of conservation-based ecotourism.

Ecotourism development requires reliable human resources and establishes good and intense cooperation between all parties (community, private sector, and government) to provide facilities and infrastructure for tourism activities (Sihite et al. 2018). The contribution of local governments, the private sector, and local communities in the development of basic infrastructure, labor training, and adequate funding can strengthen sustainable tourism development, leading to the creation of labor and economic such as in the development of ecotourism in Lake Toba, North Sumatra (Anele 2021). Kamaludin et al. (2020) reported that the development strategy of Balek Angin Lake in West Kalimantan required collaboration with local communities, local governments, NGOs, academicians, and other stakeholders to promote ecosystem protection. Achmad et al. (2020) also reported that the development of the potential of Matano Lake in South Sulawesi required the active role of managers, cooperation of stakeholders, increased information, and promotion of tourism potential.

\section{Conclusions}

The Nya'deng Lake has exceptional natural potential as an ecotourism destination. The lake is unique because it is located within an undisturbed tropical rain forest. In addition, there are other interesting objects in the surrounding lake area to be part of a tour package. An assessment of the natural tourist attractions and objects (ODTWA) element has proven that the lake can be developed and made a development priority in the region. However, multi-stakeholder collaboration is urgently needed in improving local institutions, introducing potential, promoting, and strengthening the concept of conservation-based ecotourism.

\section{Acknowledgments}

The authors thank East Kutai STIPER for supporting this study. The authors also appreciate Kerima Puri and the students of the Forestry Study Program, who have assisted this study.

\section{References}

Achmad, A., Asrianny, A., Amri, A. and Putri, A. U. B. 2020. Kajian Potensi dan Strategi Pengembangan Ekowisata di Danau Matano Kabupaten Luwu, Sulawesi Selatan. PERENNIAL 16(1): 26-33. DOI: 10.24259/perennial.v16i1.7631

Achmad, A., Ngakan, P. O., Umar, A. and Asrianny, A. 2012. Identifikasi Tutupan Vegetasi dan Potensi Fisik Lahan untuk Pengembangan Ekowisata di Laboratorium Lapangan Konservasi Sumberdaya Hutan dan Ekowisata Hutan Pendidikan UNHAS. Jurnal Penelitian Kehutanan Wallacea 1(2): 87-102. DOI: 10.18330/jwallacea.2012.vol1 iss2pp87-102 
Açıksöz, S., Cetinkaya, G. C., Uzun, O., Erduran Nemutlu, F., and Ilke, E. F. 2016. Linkages Among Ecotourism, Landscape and Natural Resource Management, and Livelihood Diversification in the Region of Suğla Lake, Turkey. International Journal of Sustainable Development World Ecology 23(1): 15-27. DOI: 10.1080/13504509.2015.1086906

Anele, K. K. 2021. An Assessment of Sustainable Tourism Development in North Sumatra. Paper presented at the In Proceedings of the International Conference on Culture Heritage, Education, Sustainable Tourism, and Innovation Technologies (CESIT).

BPS Berau. 2021. Kecamatan Kelay Dalam Angka. Tanjung Redeb: Badan Pusat Statistik (BPS) Kabupaten Berau.

Brockerhoff, E. G., Barbaro, L., Castagneyrol, B., Forrester, D. I., Gardiner, B., GonzálezOlabarria, J. R., and Taki, H. 2017. Forest Biodiversity, Ecosystem Functioning and the Provision of Ecosystem Services. Biodiversity Conservation 26: 3005-3035. DOI: 10.1007/s10531-017-1453-2

Buckley, R. 2011. Tourism and Environment. Annual Review of Environment Resources 36: $397-$ 416. DOI: 10.1146/annurev-environ-041210-132637

Butarbutar, R., and Soemarno. 2013. Environmental Effects of Ecotourism in Indonesia. Journal of Indonesian Tourism Development Studies 1(3): 97-107.

Edwin, M., Sulistyorini, I. S., and Allo, J. K. 2017. Assessment of Natural Resources and Local Community Participation is Nature-Based Tourism of Wehea forest, East Kalimantan. Jurnal Manajemen Hutan Tropika 23(3): 128-139. DOI: 10.7226/jtfm. .3.123 28

Fathoni, W. A., Widyastuti, M., Haryono, E., Fatchurahman, H., and Labib, M. A. 2020. Hydrological exploration in Karst Suaran, Berau, East Kalimantan, Indonesia. E3S Web of Conferences 200: 06005. DOI: 10.1051/e3sconf/202020006005

Harbi, J., Erbaugh, J. T., Sidiq, M., Haasler, B., and Nurrochmat, D. R. 2018. Making a Bridge Between Livelihoods and Forest Conservation: Lessons from Non Timber Forest Products' Utilization in South Sumatera, Indonesia. Forest Policy Economics 94: 1-10. DOI: 10.1016/j.forpol.2018.05.011

Kamaludin, K., Antonius, A., Emanuel, V., Nikodimus, N., Sinaga, M., and Setiawan, H. 2020. Strategy Formulation of Balek Angin Lake as an Ecotourism Attraction to Support Sintang Regency's Sustainable Development Program. Journal of Indonesian Tourism Development Studies 8(3): 165-173. DOI: 10.21776/ub.jitode.2020.008.03.06

Ministry of Forestry. 2003. Pedoman Analisis Daerah Operasi Obyek Daya Tarik Wisata Alam (ADO-ODTWA). Bogor: Direktur Jenderal Perlindungan Hutan dan Konservasi Alam

Nugroho, I., Negara, P. D., and Yuniar, H. R. 2018. The Planning and the Development of the Ecotourism and Tourism Village in Indonesia: A Policy Review. Journal of Socioeconomics 1(1): 43-51. DOI: 10.31328/jsed.v1i1.532

Pulungan, M. S. 2013. Optimalisasi Pengembangan Potensi Ekowisata sebagai Objek Wisata Andalan di Kabupaten Kutai Kartanegara Provinsi Kaltim. Jurnal Bina Praja: Journal of Home Affairs Governance 5(3): 205-214.

Rahma, N. E., Rositah, E., Pramono, D. A., Widyasasi, D., and Fariyanti, F. 2020. Valuasi Jasa Lingkungan Hutan Tropis: Studi Kasus Beberapa Kampung di Kalimantan Timur. Jurnal Riset Pembangunan 2(2): 67-78. DOI: 10.36087/jrp.v2i2.58

Reinhart, H., Labib, M. A., and Haryono, E. 2020. Speleogenetic Process of Suaran Block, Karst of Sangkulirang-Mangkalihat, East Kalimantan. E3S Web of Conferences 200: 06011. DOI: $10.1051 / \mathrm{e} 3$ sconf $/ 202020006011$ 
Roy, J., Hadjaat, M., Darma, D. C., Zainurossalamia, S., and Kasuma, J. 2021. Eksplorasi Pariwisata Pedesaan di Hutan Desa Merabu, Berau (Indonesia). Jurnal Pariwisata Pesona 6(1): 36-48. DOI: 10.26905/jpp.v6i1.5641

Roy, J., Kuncoro, M., and Darma, D. C. 2019. Kajian Dampak Ekonomi Hutan Desa Terhadap Pendapatan Petani Kampung Merabu (Kabupaten Berau, Provinsi Kalimantan Timur). Iqtishoduna 15(2): 197-216.

Sihite, R. Y., Setiawan, A., and Dewi, B. S. 2018. Potensi Obyek Wisata Alam Prioritas di Wilayah Kerja KPH Unit XIII Gunung Rajabasa, Way Pisang, Batu Serampok, Provinsi Lampung. Jurnal Sylva Lestari 6(2): 84-93. DOI: 10.23960/js12684-93

Sisriany, S., and Furuya, K. 2020. Ecotourism Policy Research Trends in Indonesia, Japan, and Australia. Jurnal Manajemen Hutan Tropika 26(2): 178-188. DOI: 10.7226/jtfm.26.2.178

Suharto, R. B., Roy, J., and Darma, D. C. 2019. Degree of Potential and Development Strategy of tourism objects. International Journal of Scientific Technology Research 8(9): 2343-2347.

Sumantri, D. I. G., Atmadja, D. A. S., and Setiawan, P. 2017. Sangkulirang Mangkalihat: The Earliest Prehistoric Rock-Art in the World. Paper presented at the Proc. of the ICA.

Wang, L. E., Zhong, L., Zhang, Y., and Zhou, B. 2014. Ecotourism Environmental Protection Measures and Their Effects on Protected Areas in China. Sustainability, 6(10), 6781-6798. DOI: $10.3390 /$ su6106781 